\title{
Estimation of Po-210 and Pb-210 Emissions from Coal Energy Use in China

\author{
ZHANG Yanqi ${ }^{a}$, JIANG Ziying ${ }^{b}$
}

China Institute of Atomic Energy, P.O.BOX 275(82), Beijing, 102413, China

a'Zhangyanqi2011@sina.com, ${ }^{\text {biziying@163.com }}$

Keywords: Po-210; Pb-210; coal energy use.

Abstract. Surveys on Po-210 and $\mathrm{Pb}-210$ levels in atmosphere in China were reviewed, and the average concentration of $\mathrm{Po}-210$ and $\mathrm{Pb}-210$ in atmosphere were $1.7 \mathrm{mBq} / \mathrm{m}^{3}$ (ranging from 0.12 to $9.4 \mathrm{mBq} / \mathrm{m}^{3}$ ) and $0.70 \mathrm{mBq} / \mathrm{m}^{3}$ (ranging from 0.03 to $1.83 \mathrm{mBq} / \mathrm{m}^{3}$ ) respectively, which are apparently higher than that the world average level. Based on emission factors method, Po-210 and $\mathrm{Pb}-210$ emissions from coal energy use in China were estimated and the result were $1.34 \times 10^{3}$ $\mathrm{GBq} / \mathrm{a}$ and $9.38 \times 10^{2} \mathrm{GBq} / \mathrm{a}$, among which utility boilers, industrial boilers and civil boilers contribute $8 \%, 31 \%$ and $60 \%$ respectively. Coal burning is the largest artificial source of excess Po210 and $\mathrm{Pb}-210$ in atmosphere in China and civil boilers is the most inefficient and polluted way of coal energy use as lacking of dust removal facilities and discharging exhaust air directly at a relatively lower height into the atmosphere. Coal-to-gas switch and coal-to-electricity switch in civil energy use should be advanced and dust removal technologies that can effectively retain volatile nuclides Po-210 and Pb-210 should be further studied.

\section{Introduction}

Natural radionuclide in the earth's continental crust may enter into the atmosphere and absorb on aerosols due to emanation migration and exhalation and other natural or human activities. Po-210 (extreme toxic nuclide, $\mathrm{T} 1 / 2=138.4 \mathrm{~d}$ ) and $\mathrm{Pb}-210$ (high toxic nuclide, $\mathrm{T} 1 / 2=22.3 \mathrm{a}$ )[1], daughters of U-238, are main radionuclide in aerosols that dominate the public doses from natural radionuclide (except radon) through inhalation and ingestion[2]. Po-210 and $\mathrm{Pb}-210$ in atmosphere may easily enter into human body through respiratory system, and may also enter in the food chain when deposited into soil and water. Under a brief review of Po-210 and $\mathrm{Pb}-210$ concentration in atmosphere from recent surveys in China, Po-210 and Pb-210 emissions from coal energy use were estimated, sources of excess Po-210 and Pb-210 were discussed, and control suggestions were proposed in this paper.

\section{Concentrations of $\mathrm{Po-210}$ and $\mathrm{Pb}-210$ in urban atmosphere}

A brief review of Po-210 and Pb-210 survey results. Surveys on Po-210 and Pb-210 concentration in atmosphere started since 1980s in China. Aerosol samples were commonly collected by using high volume air sampler or high volume cascade impactor. Po-210 analysis was mainly conducted using alpha spectrometry with radiochemical purification[3,4,5,6], and $\mathrm{Pb}-210$ analysis was mainly conducted by HPGe detector[6,7,8,9,10]. Programmed monitoring in urban atmosphere started since 2013 by the Ministry of Environmental Protection (MEP) of China. Survey results of Po-210 and $\mathrm{Pb}-210$ concentration in atmosphere were shown in table 1 . The weighted (by population) average concentration of $\mathrm{Pb}-210$ is $1.7 \mathrm{mBq} / \mathrm{m}^{3}$, ranging from 0.12 to $9.4 \mathrm{mBq} / \mathrm{m}^{3}$, and Po-210 is $0.70 \mathrm{mBq} / \mathrm{m}^{3}$, ranging from 0.03 to $1.83 \mathrm{mBq} / \mathrm{m}^{3}$, which are apparently higher than the world environmental average level (the reference value of $\mathrm{Pb}-210$ and $\mathrm{Po}-210$ concentration in atmosphere are $0.5 \mathrm{mBq} / \mathrm{m}^{3}$ and $0.05 \mathrm{mBq} / \mathrm{m}^{3}$ respectively[2]). 
Table 1. Po-210 and $\mathrm{Pb}-210$ concentration in atmosphere in China .

\begin{tabular}{|c|c|c|c|c|c|c|c|c|}
\hline \multirow{2}{*}{ Location } & \multicolumn{4}{|c|}{$\mathrm{Pb}-210$ concentration $\left[\mathrm{mBq} / \mathrm{m}^{3}\right]$} & \multicolumn{4}{|c|}{ Po- 210 concentration $\left[\mathrm{mBq} / \mathrm{m}^{3}\right]$} \\
\hline & samples & mean & range & references & samples & mean & range & references \\
\hline Hefei & 18 & 2.0 & $0.23-5.9$ & {$[11,12]$} & & & & \\
\hline Beijing & 48 & 1.5 & $0.55-3.5$ & {$[10,11,12]$} & 1 & 0.81 & & [10] \\
\hline Fuzhou & 1 & 2.7 & & {$[10]$} & 1 & 0.75 & & [10] \\
\hline Lanzhou & 1283 & 0.8 & $0.12-4.33$ & {$[7,10]$} & 1 & 1.62 & & [10] \\
\hline Guangzhou & 23 & 1.4 & $0.12-2.8$ & {$[11,12]$} & 9 & 0.23 & $0.03-0.41$ & [12] \\
\hline Shaoguan & 16 & 0.6 & $0.25-1.3$ & {$[11,12]$} & & & & \\
\hline Maoming & 16 & 0.6 & $0.11-1.6$ & {$[11,12]$} & & & & \\
\hline Guilin & 14 & 0.9 & $0.27-1.9$ & {$[11,12]$} & & & & \\
\hline Nanning & 37 & 1.6 & $0.22-6.0$ & {$[10,11,12]$} & 2 & 0.59 & $0.30-0.87$ & {$[10,12]$} \\
\hline Baise & 14 & 1.1 & $0.45-1.9$ & {$[11,12]$} & & & & \\
\hline Guiyang & 110 & 2.7 & $0.7-7.4$ & {$[6,10,12]$} & 4 & 0.61 & $0.18-1.12$ & {$[10,12]$} \\
\hline Haikou & 9 & 1.2 & $0.20-3.1$ & {$[10,11]$} & 8 & 0.35 & $0.14-0.85$ & {$[10,11]$} \\
\hline Sanya & 2 & 0.7 & $0.39-0.95$ & {$[11]$} & 1 & 0.34 & & [11] \\
\hline Zhengzhou & 2 & 1.3 & $0.60-2.04$ & {$[10,11]$} & 1 & 1.39 & & [10] \\
\hline Hengyang & & & & & 7 & 1.83 & & [10] \\
\hline Changsha & 4 & 1.9 & $1.43-2.2$ & {$[10,12]$} & 4 & 0.50 & $0.16-0.79$ & {$[10,12]$} \\
\hline Changchun & 1 & 2.7 & & {$[10]$} & 1 & 0.99 & & {$[10]$} \\
\hline Nanjing & 1 & 1.2 & & [10] & 1 & 0.82 & & [10] \\
\hline Nanchang & 11 & 1.7 & $0.28-2.67$ & {$[10,11,12]$} & 2 & 1.10 & $0.58-1.62$ & {$[10,12]$} \\
\hline Shangrao & 7 & 1.7 & $0.79-2.8$ & [12] & & & & \\
\hline Jiujiang & 7 & 0.8 & $0.44-1.6$ & [12] & & & & \\
\hline Shenyang & 23 & 2.9 & $1.2-6.7$ & {$[10,11,12]$} & 4 & 0.62 & $0.23-1.26$ & {$[10,12]$} \\
\hline Baotou & 1 & 3.6 & & [12] & 2 & 0.33 & $0.32-0.33$ & {$[10,12]$} \\
\hline Xining & 2 & 2.8 & $2.4-3.2$ & [12] & & & & \\
\hline $\begin{array}{l}\text { Mt. } \\
\text { Waliguan }\end{array}$ & 67 & 1.64 & $0.7-5.3$ & [9] & & & & \\
\hline Jinan & 2 & 1.8 & $0.36-3.3$ & {$[11,12]$} & 2 & 0.50 & $0.19-0.81$ & {$[11,12]$} \\
\hline Qingdao & 1 & 1.7 & & {$[12]$} & 1 & 0.14 & & [12] \\
\hline Taiyuan & 1 & 2.08 & & [10] & 1 & 1.29 & & [10] \\
\hline Xi'an & 1 & 1.9 & & {$[10]$} & 1 & 0.97 & & [10] \\
\hline Chengdu & 13 & 2.7 & $0.66-9.4$ & [11] & 7 & 0.32 & $0.16-0.59$ & [12] \\
\hline Tianjin & 9 & 1.3 & $0.81-2.2$ & {$[10,12]$} & 10 & 0.66 & $0.42-1.13$ & {$[10,12]$} \\
\hline Lhasa & 1 & 1.5 & & [10] & 1 & 0.86 & & [10] \\
\hline Urumchi & 1 & 0.5 & & [10] & 1 & 0.23 & & [10] \\
\hline Kunming & 12 & 1.0 & $0.29-1.7$ & {$[10,11,12]$} & 10 & 0.44 & $0.11-1.26$ & {$[10,11,12]$} \\
\hline Hangzhou & 130 & 1.3 & $0.12-2.74$ & {$[3,10,12]$} & 110 & 0.31 & $0.06-1.22$ & {$[3,10,12]$} \\
\hline Average & & 1.7 & $0.12-9.4$ & & & 0.70 & $0.03-1.83$ & \\
\hline
\end{tabular}

Sources of excess Po-210 and Pb-210 in atmosphere. Sources of Po-210 and Pb-210 in atmosphere include migration, exhalation and decay of Rn-222 from soil, resuspension of surface soil, eruption of volcanic plumes, emission of biovolatile species[13,14], as well as from human activities ( for example, coal burning, coking, iron and steel smelting, cement production, nonferrous metallurgy and so on) and are therefore naturally occurring radioactive materials (NORM). At present, crude steel output in China accounts for about 44\% the world's total[15], raw coal output accounts for about 47\%[16] and cement output accounts for about 60\%[17]. Po and $\mathrm{Pb}$, as volatile elements, may attach to fine particles and escape into the atmosphere, which results in increased concentration and extra radiation doses to the public. Coal consumption, accounting for $70 \%$ of primary energy consumption in China[16], is an important artificial source of excess Po-210 and $\mathrm{Pb}-210$ in atmosphere. 


\section{Estimation of $\mathrm{Po-210}$ and $\mathrm{Pb}-210$ emissions from coal energy use}

Coal consumption in China. Coal is major energy source and contributes about $70 \%$ of the total energy consumption in China[16]. Figure 1[18] shows the variation of coal consumption since 1990 in China. The total consumption first declined in 2014, however the total consumption in 2014 is 2 more times higher than that in 2000. The coal consumption in 2015 is about 4300 Mtce, among which power generation, civil usage, and industrial and others accounts for $50 \%, 5 \%$ and $45 \%$ respectively[19].

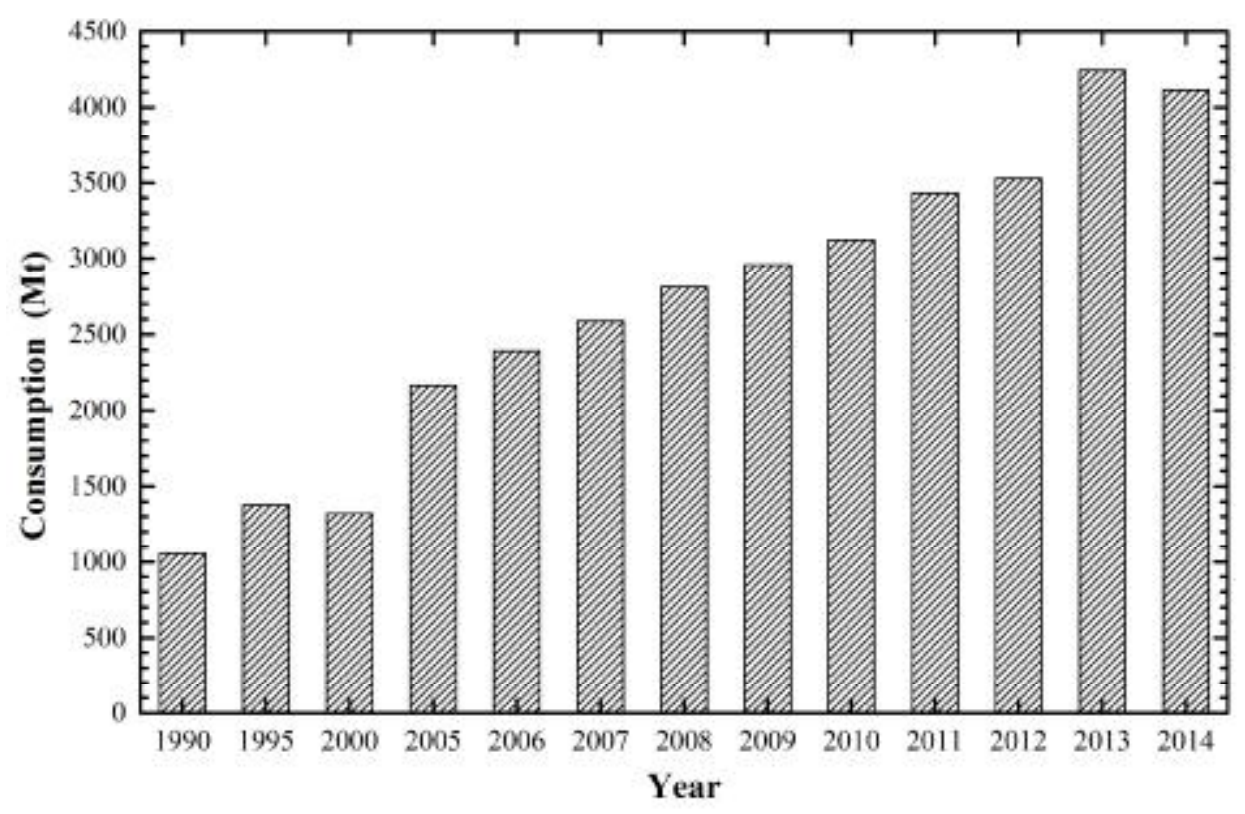

Figure 1. Coal consumption in China.

Method and data. Based on emission factors method[20], the emissions of radionuclide (M) from coal burning (in Bq/a) can be calculated by formula (1):

$$
\mathrm{M}=\sum_{i, j} \mathrm{C}_{i} \times \mathrm{EF}_{p m, j} \times \mathrm{EF}_{i} \times \mathrm{G}_{j}
$$

where $\mathrm{C}_{i}$ is content of the natural radionuclide $i$ in coal (in $\mathrm{Bq} / \mathrm{kg}$ ), $\mathrm{EF}_{p m, j}$ is $\mathrm{PM}$ emission factor of coal burning activity $j$ (in $\mathrm{kg} / \mathrm{t}$ ), $\mathrm{EF}_{\mathrm{i}}$ is enrichment factor of natural radionuclide $i$ depending on particle sizes, and $\mathrm{G}_{j}$ is the coal consumption (in $\mathrm{t} / \mathrm{a}$ ).

Measurement results of radionuclide content in coal in recent surveys were summarized in table 2. The recommendation of radionuclide content in coal used for $M$ estimation for U-238, Ra-226, Po-210 and Pb-210 are $40 \mathrm{~Bq} / \mathrm{kg}, 35 \mathrm{~Bq} / \mathrm{kg}, 30 \mathrm{~Bq} / \mathrm{kg}$, and $35 \mathrm{~Bq} / \mathrm{kg}$ respectively in China.[21]

Table 2. Content of radionuclide in coal in China.

\begin{tabular}{ccccccc}
\hline \multirow{2}{*}{ Years } & \multirow{2}{*}{ Samples } & \multicolumn{5}{c}{ Activity content $[\mathrm{Bq} / \mathrm{kg}]$} \\
\cline { 3 - 6 } & & $\mathrm{U}-238$ & $\mathrm{Ra}-226$ & $\mathrm{~Pb}-210$ & Po-210 & References \\
\hline 1989 & $563^{\mathrm{a}}$ & & $26(2-2300)$ & & {$[22]$} \\
1989 & $7^{\mathrm{b}}$ & $67.7 \pm 14.1$ & $37.2 \pm 17.6$ & $18.6 \pm 4.9$ & $8.6 \pm 3.9$ & {$[23]$} \\
2002 & $621 / 442^{\mathrm{c}}$ & 37.5 & & & & {$[24]$} \\
2007 & $1014^{\mathrm{d}}$ & $79.5 \pm 45$ & $73.9 \pm 53$ & & & {$[25]$} \\
2016 & $76^{\mathrm{e}}$ & $31.2(2.1-525.8)$ & $26.9(1.4-699.0)$ & $26.3(1.7-182.5)$ & $22.2(2.5-86.4)$ & {$[21]$} \\
\hline
\end{tabular}

${ }^{\mathrm{a}}$ sampled from 100 mines. ${ }^{\mathrm{b}}$ sampled from 6 mines. ${ }^{\mathrm{c}}$ sampled nationwide. ${ }^{\mathrm{d}}$ sampled nationwide. ${ }^{\mathrm{e}}$ sampled from 66 mines.

Coal burning boilers used in China may be classified into 3 types: utility units of coal-fired power generation, industrial boilers and civil boilers, and each of them are equipped with different 
type of dust removal facilities (or not). Utility units with capacity higher than $300 \mathrm{MW}$ contributing $78 \%$ the total capacity in China. High efficiency dust removal facilities are widely equipped to these units, among which electric precipitator and bag and electric bag filters accounts for $77 \%$ and $23 \%$ respectively, and the average dust removal efficiency can reach to $99.75 \%$. However, utility units with capacity below $100 \mathrm{MW}$ (accounts for about 9\% of total capacity) and large numbers of industrial boilers equipped dust removal facilities with lower efficiency. Especially, civil boilers usually not equipped dust removal facilities, and briquette and bulk coal are widely used as fuels (accounts for about $80 \%$ of total civil coal consumption) which are inferior with higher ash component and lower quality. Measurement results of $\mathrm{PM}_{2.5}$ emission factor of various types of boilers were listed in table $3 . \mathrm{PM}_{2.5}$ emission factor of civil boilers is 1 - 2 orders of magnitude higher than other type of boilers. In this estimation, $\mathrm{PM}_{2.5}$ emission factor of utility boilers was selected as $0.07 \mathrm{~kg} / \mathrm{t}$ (ranging from 0.06 to $0.19 \mathrm{~kg} / \mathrm{t}$ ), for industrial boilers was $0.29 \mathrm{~kg} / \mathrm{t}$ (ranging from 0.032 to $0.486 \mathrm{~kg} / \mathrm{t}$ ), and for civil boilers was $5 \mathrm{~kg} / \mathrm{t}$ (ranging from 1 to $11 \mathrm{~kg} / \mathrm{t}$ ).

Table 3. $\mathrm{PM}_{2.5}$ emission factors of different types of boilers.

\begin{tabular}{ccccc}
\hline Boiler type & Boiler parameter & Dust removal facility & $\begin{array}{c}\text { Emission factors } \\
{[\mathrm{kg} / \mathrm{t}]}\end{array}$ & References \\
\hline Utility & $35-100 \mathrm{t} / \mathrm{h}$ & ESP $^{\mathrm{a}}$ & $0.145(0.122-0.186)$ & {$[26]$} \\
& $200 \mathrm{t} / \mathrm{h}$ & ESP & 0.0754 & {$[26]$} \\
& $220 \mathrm{t} / \mathrm{h}$ & ESP, Bag filter & 0.13 & {$[27]$} \\
& $250 \mathrm{t} / \mathrm{h}$ & ESP & 0.079 & {$[26]$} \\
Industrial & $1025 \mathrm{t} / \mathrm{h}$ & ESP & 0.06 & {$[27]$} \\
& $2 \mathrm{t} / \mathrm{h}$ & Multicyclone,WESP & $0.17(0.10-0.185)$ & {$[28,29]$} \\
& $3 \mathrm{t} / \mathrm{h}$ & WESP & 0.338 & {$[28,30]$} \\
& $4 \mathrm{t} / \mathrm{h}$ & WESP, Cyclone $^{\mathrm{b}}$ & $0.16(0.032-0.209)$ & {$[28-32]$} \\
& $8 \mathrm{t} / \mathrm{h}$ & D\&D & 0.25 & {$[27]$} \\
& $10 \mathrm{t} / \mathrm{h}$ & WESP, Bag filter, D\&D & $0.33(0.072-0.52)$ & {$[27]$} \\
Civil & $25 \mathrm{t} / \mathrm{h}$ & D\&D & 0.17 & {$[27]$} \\
& Briquette & None & 0.8 & {$[20]$} \\
& Anthracite & None & 1.4 & {$[20]$} \\
& Bituminite & None & 10.8 & {$[20]$} \\
& Semi-coke & None & 1.1 & {$[20]$} \\
\hline
\end{tabular}

${ }^{a}$ ESP: electrostatic precipitator. ${ }^{b}$ WESP: wet electrostatic precipitator. ${ }^{c}$ D\&D: desulfurization and dust separation.

Bottom ash retains most of the radionuclide after coal burning. While the fly ash particles provide condensate nuclei for radionuclide, especially for volatile radionuclide such as Po-210 and $\mathrm{Pb}-210$, making them easily escape into the atmosphere. The particle size smaller, the higher radionuclide enrichment (usually $\mathrm{PM}_{10}<\mathrm{PM}_{2.5}<\mathrm{PM}_{1}$ ). Considering the boiler types, burning conditions and dust removal equipment, Po-210 emission factor (within $\mathrm{PM}_{2.5}$ ) was selected as 25 and $\mathrm{Pb}-210$ was 15 [33-35].

Estimation results and discussions. The estimated $\mathrm{Po}-210$ and $\mathrm{Pb}-210$ annual emissions (based on the consumption of 2015) from coal burning in China is $1.34 \times 10^{3} \mathrm{GBq}$ and $9.38 \times 10^{2} \mathrm{GBq}$ respectively, as shown in Table 4 . Utility boilers, industrial boilers and civil boilers contribute $8 \%$, $31 \%$ and $60 \%$ respectively of total $\mathrm{Po}-210$ and $\mathrm{Pb}-210$ emission from coal burning in China. Civil boilers are the most inefficient and polluted way of energy use and the most important source of human induced Po-210 and $\mathrm{Pb}-210$ emissions. 
Table 4. Po-210 and Pb-210 emissions from coal burning in China (based on 2015) [GBq/a]

\begin{tabular}{ccc}
\hline Boiler type & Po-210 & Pb-210 \\
\hline Utility & $1.13 \times 10^{2}$ & $7.90 \times 10^{1}$ \\
Industrial & $4.21 \times 10^{2}$ & $2.95 \times 10^{2}$ \\
Civil & $8.06 \times 10^{2}$ & $5.64 \times 10^{2}$ \\
Total & $1.34 \times 10^{3}$ & $9.38 \times 10^{2}$ \\
\hline
\end{tabular}

\section{Summary and suggestions}

Average of Po-210 and Pb-210 concentration in atmosphere in China is 0.7 and $1.70 \mathrm{mBq} / \mathrm{m}^{3}$ respectively, which are apparently higher than the world environmental average level. NORM industry activities such as coal burning are important source of excess $\mathrm{Po}-210$ and $\mathrm{Pb}-210$. Civil boilers are the most inefficient and polluted way of energy use and the most important Po-210 and $\mathrm{Pb}-210$ emission sources in China. Coal-to-gas switch and coal-to-electricity switch in civil energy use should be advanced to reduce the civil coal consumption. As extreme toxic and high toxic volatile natural radionuclide, $\mathrm{Po}-210$ and $\mathrm{Pb}-210$ are easily attached to fine particles (as fly ash/PM2.5) and discharge into the atmosphere, thus induce extra radiation doses to the public. Therefore, dust removal technologies that can effectively retain volatile nuclides $\mathrm{Po}-210 \mathrm{and} \mathrm{Pb}-$ 210 should be further studied.

\section{References}

[1] LU Xiting: 1981 Nuclear Physics Atomic Energy Press 33 (in Chinese)

[2] United Nations: Scientific Committee on the Effects of Atomic Radiation 2000 SOURCES AND EFFECTS OF IONIZING RADIATION 1123

[3] Cao Zhonggang et al.: 2016 Proceedings of 4th NORM Radiation and Control Seminar (14th conference of 21st Centry Forum on Radiation Protection) 211 (in Chinese)

[4] SHAN Jian et al.: 2014 Nuclear Electronics \& Detection Technology 34(8) 958 (in Chinese)

[5] ZHAO Lancai et al.: 1992 Chinese Journal of Radiological Medicine and Protection 12(6) 371 (in Chinese)

[6] WAN Guojiang et al.: 2005 Chinese Science Bulletin 50(14) 1498 (in Chinese)

[7] WANG Yun et al.: 2014 Nuclear Electronics \& Detection Technology 34(1) 114 (in Chinese)

[8] SONG Haiqing et al.: 2003 Proceedings of Symposium on monitoring and evaluation of radioactive efffluents and environment in China 484 (in Chinese)

[9] Zheng Xiangdong et al.: 2005 Chinese Science Bulletin 50(1) 72 (in Chinese)

[10] Li Jiaxing et al.: 2013 Radiation Protection Bulletin 33(3) 25 (in Chinese)

[11] MEP: 2014 ANNUAL REPORT OF THE NATIONAL RADIATION ENVIRONMENT 2013 (in Chinese)

[12] MEP: 2015 ANNUAL REPORT OF THE NATIONAL RADIATION ENVIRONMENT 2014 (in Chinese)

[13] Ge Yan et al.: 2012 Atmospheric Environment 5480

[14] Zhang Jing et al.: 2015 Radiation Protection Bulletin 36(6) 17 (in Chinese)

[15] ZHANG Jialin et al.: 2014 World Economic Papers 41 (in Chinese)

[16] WANG Shiwen: 2011 On Economic Problems 1138 (in Chinese) 
[17] Gong Xiumei et al.: 2013 Cement Guide for New Epoch 43 (in Chinese)

[18] National Bureau of Statistics: 2008-2016 CHINA STATISTICAL YEARBOOK 2008-2016 China Statictics Press (in Chinese)

[19] China Association of Rural Energy Industry 2016 (in Chinese)

[20] MEP: 2016 Technical guidelines for discharge of atmospheric pollutants list compilation for civil coal (in Chinese)

[21] Chinese Academy of Engineering: 2017 Radiation impact evaluation of nuclear power chain and coal power chain Not pressed (in Chinese)

[22] Jiang Xiwen et al.: 1989 Radiation Protection 9(3) 181 (in Chinese)

[23] WU Jinhai et al.: 1989 Shanghai Environmental Sciences 8(1) 28 (in Chinese)

[24] HUANG Wenhui et al.: 2002 Coal Geology of China 1455 (in Chinese)

[25] Liu Fudong et al.: 2007 Radiation Protection 27(3) 171 (in Chinese)

[26] Wang S et al.: 2011 Acta Scientiae Circumstantiae 31(3) 630 (in Chinese)

[27] WEN Yanping et al.: 2014 Journal of Taiyuan University of Technology 45(6) 712 (in Chinese)

[28] Lou S R: 2014 Acta Scientiae Circumstantiae 34(12) 3119 (in Chinese)

[29] LI Chao et al.: 2009 Environmental Science 30(3) 650 (in Chinese)

[30] GENG Chunmei et al.: 2013 Research of Ernvironmental Sciences 26(6) 666 (in Chinese)

[31] ZHOU N et al.: 2006 Acta Scientiae Circumstantiae 26(5) 764 (in Chinese)

[32] WANG Shuxiao et al.: 2009 Environmental Science 30(4) 963 (in Chinese)

[33] David G Coles et al.: 1978 Environmental Science \& Technology 12442

[34] YA-HUI WENG et al.: 1992 J. RADIAT. RES. 33141

[35] S K Sahu et al.: 2014 Journal of Environmental Radioactivity 138421 